\title{
Anti-Proliferative Properties of Cornus mass Fruit in Different Human Cancer Cells
}

\author{
Bahman Yousefi ${ }^{1,2}$, Mozhgan Abasi ${ }^{3}$, Mehran Mesgari Abbasi ${ }^{2,4}$, Rana Jahanban- \\ Esfahlan $^{2,3 *}$
}

\begin{abstract}
Background: There is a long standing interest in natural compounds especially those with a high polyphenolic content and high scavenging activity for hazardous free radicals. Cornus mas (CM) fruit is well known for its antioxidant activities; however, its toxicity against human cancers needs to be addressed. Here, we investigated selective anticancer effects of $\mathrm{CM}$ on different human cancer cells. Materials and Methods: A hydro-alcoholic extract of CM (HECM) was prepared and total phenolic content (TPC) and total flavonoid content (TFC) were determined by colorimetric assays. Antioxidant activity was assessed with respectto DPPH radical scavenging. MTT assays were used to evaluate the cytotoxicity of different doses of $\mathrm{CM}(0,5,20,100,250,500,1000 \mu \mathrm{g} /$ ml) towards A549 (lung non small cell cancer), MCF-7 (breast adenocarcinoma), SKOV3 (ovarian cancer) and PC-3 (prostate adenocarcinoma) cells. Results: Significant $(\mathbf{P}<0.05)$ or very significant $(\mathbf{P}<0.001)$ differences were observed in comparison to negative controls at all tested doses $(5-1000 \mu \mathrm{g} / \mathrm{ml})$. In all cancer cells, HECM reduced the cell viability to values below $26 \%$, even at the lowest doses. In all cases, $\mathrm{IC}_{50}$ was obtained at doses below $5 \mu \mathrm{g} / \mathrm{ml}$. The mean growth inhibition was $81.8 \%, 81.9 \%, 81.6 \%$ and $79.3 \%$ in SKOV3, MCF-7, PC-3 and $\mathbf{A 4 9}$ cells, respectively. Conclusions: Altogether, to our best knowledge, this is a first study that evaluated toxicity of a HECM with high antioxidant activity in different human cancer cells in vitro. Our results indicated that a hydro-alcoholic extract of CM possesses high potency to inhibit proliferation of different tumor cells in a dose independent manner, suggesting that an optimal biological dose is more important and relevant than a maximally tolerated one .
\end{abstract}

Keywords: Cornus Mas - A549 - SKOV3 - MCF-7 - PC-3 - anti proliferative effects

Asian Pac J Cancer Prev, 16 (14), 5727-5731

\section{Introduction}

Cornus mas L. (Cornaceae family) known as the Asiatic and European cornelian cherry is a species of dogwood native to Southwest Asia and Southern Europe. Cornelian cherry is an obviously growing dogwood species in Arasbaran (East Azerbaijan, Iran). It is a medium to large deciduous shrub or small tree growing to $5-12 \mathrm{~m}$ tall, with dark brown branches and greenish twigs(Tural and Koca, 2008). The fruit is an oblong, red drupe $2 \mathrm{~cm}$ long and $1.5 \mathrm{~cm}$ in diameter, containing a single seed. The ripe fruit is safe to eat, but the unripe is astringent (Figure 1). The most common use of cornelian cherry fruits is to produce diverse drinks, sweets, gels, and jams. Extract from the fruits is also used in Europe for cosmetic purposes (Seeram et al., 2002).

Many natural compounds, phenolics and in particular flavonoids were found to be an important part of human diet and are considered as active principles in many medicinal plants. In addition, flavonoids with their subclass anthocyanins, contribute the yellow, orange, red, and blue color to flowers, fruits, and vegetables, and could become important in the replacing of the synthetic pigments by the natural ones (Jahanban-Esfahlan et al., 2010; Jahanban-Esfahlan et al., 2012).

Cornelian cherry fruits contain considerable amounts of anthocyanins (ANTs). Recent studies showed that the berries of C. mas contain five ANTs, identified by paper chromatography, spectrophotometric, and peroxide oxidation analysis as cyaniding 3-galactoside, pelargonidin 3-galactoside, cyanidin 3-rhamnosylgalactoside, delphinidin 3-galactoside, and pelargonidin 3-rhamnosylgalac toside (Du and Francis, 1937).

A pharmacological study shown that ANTs of cornelian cherry are the combination of three compounds: cyanidin 3-O galactoside, delphinidin 3-O-galactoside, and pelargonidin 3-O-galactoside(Seeram et al., 2002). Another study showed that three main ANTs of C. Mas are cyanidin 3-O-rutinoside, pelargonidin 3-O glucoside, and cyanidin 3-O-glucoside. C. mas is used in the preparation of beverages in Europe and also to treat diabetes-related

${ }^{1}$ Department of Biochemistry and Clinical Laboratories, Faculty of Medicine, ${ }^{2}$ Research Committee, ${ }^{3}$ Department of Medical Biotechnology, Faculty of Advanced Medical Sciences, ${ }^{4}$ Drug Applied Research Center, Tabriz University of Medical Sciences, Tabriz,Iran*For correspondence: jahanbanr@tbzmed.ac.ir 
Bahman Yousefi et al

disorders in Asia (Tural and Koca, 2008).

Cornus Mas (CM) fruit is well known for its antioxidant activities; however, its toxicity on human cancers is not studied. In following study, we investigated the selective anticancer effects of CM on different human cancer cells.

\section{Materials and Methods}

\section{Preparation of extracts}

Cornus Mas fruits collected from Kaleibar region, East Azerbaijan Province, Iran, in Jun 2014. The fruits were shade dried, and grinded into powder with mortar and pestle. The prepared powder was kept in tight containers protected completely from light. Extraction of hydroalcoholic extract (HAE) was carried out according to the previous protocols (Valiyari $S$ et al., 2013; Sineh Sepehr et al., 2014) by macerating $100 \mathrm{~g}$ of powdered dry fruit in $500 \mathrm{~mL}$ of $80 \%$ ethanol for $48 \mathrm{~h}$ at room temperature. Then, the macerated fruit material was extracted with $80 \%$ ethanol solvent by percolator apparatus (2-liter volume) at $25 \mathrm{c}$. The fruit extract was removed from percolator, filtered through Whatman filter paper (NO. 4), and dried under reduced pressure at $37^{\circ} \mathrm{C}$ with rotatory evaporator. The concentrated fruit extracts were dissolved in Phosphate Buffer Saline (PBS) and was filtered to obtain a stock solution of $10 \mathrm{mg} / \mathrm{mL}$. Subsequently, the substocks with concentrations ranging from $5 \mu \mathrm{g} / \mathrm{ml}-1000 \mu \mathrm{g} / \mathrm{ml}$ was prepared from stock and further used in MTT assay.

\section{Determination of total phenolic content (TPC)}

Total phenolic content was determined with FolinCiocalteu Reagent (FCR) according to the a described method (Singleton and Rossi, 1965) with some modifications. Briefly, $0.5 \mathrm{ml}$ of each phenolic extract was mixed with $2 \mathrm{ml}$ of $7.5 \%$ sodium carbonate, and then the mixture was allowed to stand at room temperature for $2 \mathrm{~min}$. After addition of $2.5 \mathrm{ml}$ ten-fold Folin-Ciocalteu reagent, the mixture was incubated in the dark room for $30 \mathrm{~min}$. The absorbance was measured at $720 \mathrm{~nm}$ by using a spectrophotometer. The results were expressed as equivalent $\mathrm{mg}$ of Gallic acid per $100 \mathrm{~g}$ of fresh mass (mg GAE/100 g FM). A standard curve for Gallic acid was plotted under the same conditions as the studied samples. All determinations were performed in triplicates.

\section{Determination of Total flavonoid content (TFC)}

Total flavonoid content of the extracts were assayed by the colorimetric method described by other authors (Zhishen et al., 1999; Jahanban-Esfahlan et al., 2012), with minor modifications. CME $(250 \mu \mathrm{l})$ was mixed with $1.25 \mathrm{ml}$ of distilled water and $75 \mu \mathrm{l}$ of a $5 \% \mathrm{NaNO} 2$ solution. After five minutes, $150 \mu \mathrm{l}$ of a $10 \% \mathrm{AlCl} 3$. H2O solution, $500 \mu \mathrm{l}$ of $1 \mathrm{M} \mathrm{NaOH}$ and $275 \mu \mathrm{l}$ of distilled water were added to the mixture. The absorbance of the mixture was measured at $507 \mathrm{~nm}$. The results were expressed as equivalent $\mathrm{mg}$ of Qurcetin per $100 \mathrm{~g}$ of fresh mass (mg $\mathrm{Q} / 100 \mathrm{~g} \mathrm{FM}$ ) and compared with the Qurcetin standard curve, which was made under the same conditions. All determinations were performed in triplicates.

\section{DPPH free radical scavenging activity}

The DPPH radical scavenging activity was determined as described by Brand-Williams et al. (Brand-Williams et al., 1995) with some modifications. Various volumes of extracts $(30,50,70$ and $100 \mathrm{~mL})$ were added to $1 \mathrm{~mL}$ of 2, 2-diphenyl-1-picrylhydrazyl (DPPH) solution (0.1 mM in methanol) and the reaction mixture shaken vigorously. After incubation at room temperature for $10 \mathrm{~min}$, the absorbance of this solution was determined at $517 \mathrm{~nm}$, by using a spectrophotometer. The antioxidant activity was expressed as $\mathrm{IC}_{50}$ values, which were calculated by nonlinear regression with a one phase exponential association equation using GraphPad Prism version 6.0.

\section{Cell culture}

SKOV3 (human ovarian carcinoma), MCF-7 (human breast adenocarcinoma), PC-3 (Human prostate adenocarcinima), A549 (lung non small cell cancer cells) were obtained from the Pasture Institute (Tehran-Iran ). Cells were grown in RPMI 1640 supplemented with $10 \%$ heat-inactivated fetal bovine serum (FBS), penicillin (10 $\mathrm{U} / \mathrm{ml})$, streptomycin $(10 \mu \mathrm{g} / \mathrm{ml})$ and $0.2 \mathrm{mM}$ sodium pyruvate. Cultures were incubated in the presence of $5 \%$ $\mathrm{CO}_{2}$ at $37^{\circ} \mathrm{C}$ and $100 \%$ relative humidified atCMsphere.

\section{MTT assay}

The cells were seeded in 96-well plates with a density of $1 \times 10^{4}$ cells/well $/ 200 \mathrm{~mL}$ and incubated for $24 \mathrm{~h}$ at $37 \mathrm{C}$ and $5 \% \mathrm{CO} 2$. The cells were treated with different concentrations of solvent extracts $(5,20,100,250,500$, $1000 \mu \mathrm{g} / \mathrm{ml}$ ). Paclitaxel (plant-derived chemotherapeutic anti-cancer drug from Taxus brevifolia) was used as a positive control. Untreated cancer cells was used as negative control $(0 \mu \mathrm{g} / \mathrm{ml}$, vehicle alone). After $72 \mathrm{~h}$ treatment, $10 \mathrm{~mL}$ of MTT reagent was added to each well. The plates were incubated at $37 \mathrm{C}$ and $5 \% \mathrm{CO}_{2}$ for $4 \mathrm{~h}$. Then, $100 \mathrm{~mL}$ of the solubilization solution was added to each well and followed by incubation overnight at 37 $\mathrm{C}$ to dissolve formazan crystals. Finally, absorbance was read using an ELISA plate reader at a wavelength of 570 $\mathrm{nm}$. The percentage of cytotoxicity and cell viability were calculated using following equation: $\%$ Cytotoxicity $=1-$ (mean absorbance of treated cells/mean absorbance of negative control) and \% Viability=100-\% Cytotoxicity.

\section{Statistical analysis}

All the data represented in this study are mean \pm SEM of three identical experiments made in three replicate. Statistical significance was determined by analysis of variance, followed by LSD test and p-value $\leq 0.01$ was considered significant. All analyses were conducted using the SPSS 16.

\section{Results and Discussion}

In the recent decades, although so much success accomplished in cancer treatment, however it still remains among the most common killers in the world (Jahanban Esfahlan et al., 2011; Abbasi et al., 2014). Among a plethora of options for cancer treatment and prevention, 
Table 1. \% Growth Inhibition of Different doses of CM on different Human Cancer Cells

\begin{tabular}{lllll}
\hline & \multicolumn{4}{c}{ \% Growth Inhibition (72h) CM extract } \\
\cline { 2 - 5 } Doses $(\mu \mathrm{g} / \mathrm{ml})$ & SKOV3 & MCF-7 & PC-3 & A549 \\
\hline 1000 & $78.25 \pm 5.2$ & $84.5 \pm 7.2$ & $80.59 \pm 6.2$ & $79.88 \pm 7.3$ \\
500 & $82.5 \pm 7.3$ & $84.41 \pm 5.3$ & $82.0 \pm 3.2$ & $78.62 \pm 6.5$ \\
250 & $86.5 \pm 6.5$ & $84.54 \pm 4.4$ & $85.0 \pm 4.8$ & $84.75 \pm 5.9$ \\
100 & $83.0 \pm 6.1$ & $80.45 \pm 8.0$ & $80.12 \pm 8.1$ & $74.08 \pm 4.4$ \\
20 & $78.2 \pm 9.2$ & $77.8 \pm 5.2$ & $81.7 \pm 8.2$ & $80.5 \pm 6.3$ \\
5 & $82.2 \pm 8.1$ & $79.41 \pm 43$ & $80.25 \pm 7.5$ & $78.16 \pm 6.7$ \\
Mean \pm SEM & $81.77 \pm 5.4$ & $81.85 \pm 4.7$ & $81.61 \pm 3.1$ & $79.31 \pm 3.4$ \\
\hline
\end{tabular}

(a)

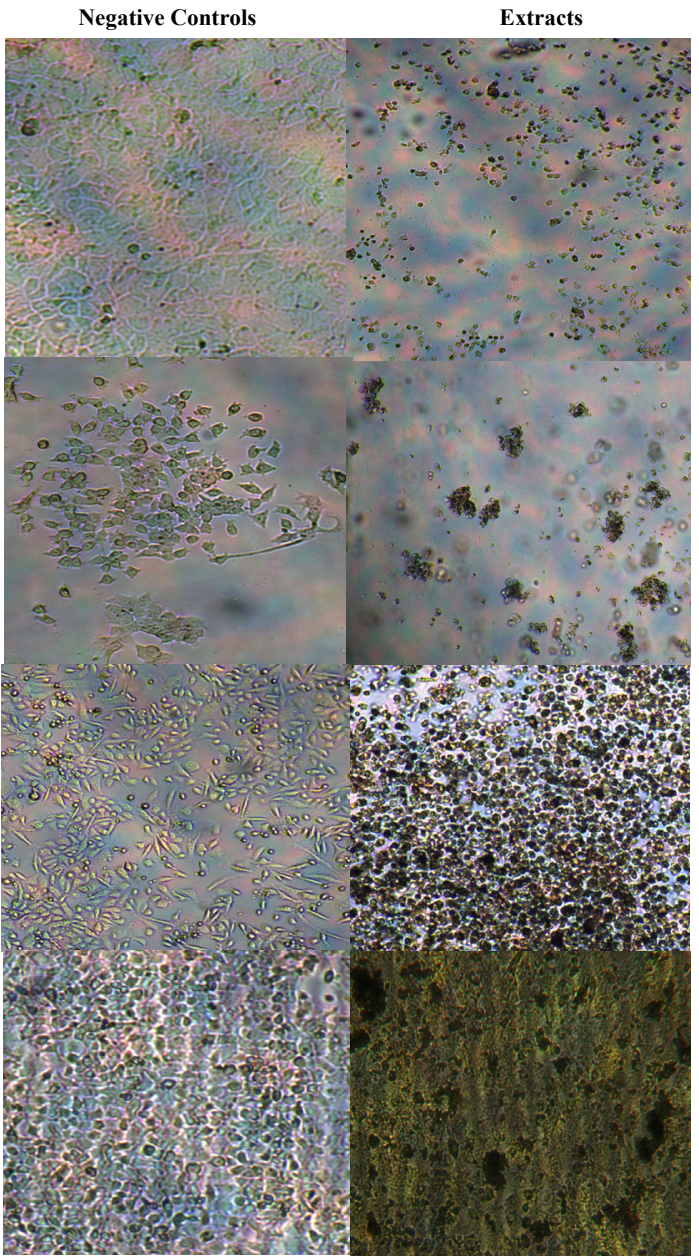

Figure 3. Cytotoxic Effect of CM on Human SKOV3 (a), MCF-7 (b), PC-3 (c) and A549 (d) Cell Lines after 72h Exposure

natural products especially those rich in antioxidants, have always being regarded as safe agents that effectively could scavenge the free radicals and protect cells from their hazardous effects which could lead to uncontrolled cell proliferation and development of cancer (JahanbanEsfahlan et al., 2010; Valiyari S et al., 2013). In this respect, Flavonoids, including anthocyanins, as one of the most diverse and widespread group of natural compounds are probably the most important natural phenolics. These compounds possess a broad spectrum of chemical and biological activities, including radical scavenging properties (Pyrkosz-Biardzka et al., 2014). Several studies have confirmed the high antioxidant activity of Cornus Mas fruit extract mostly ascribed to its high content of

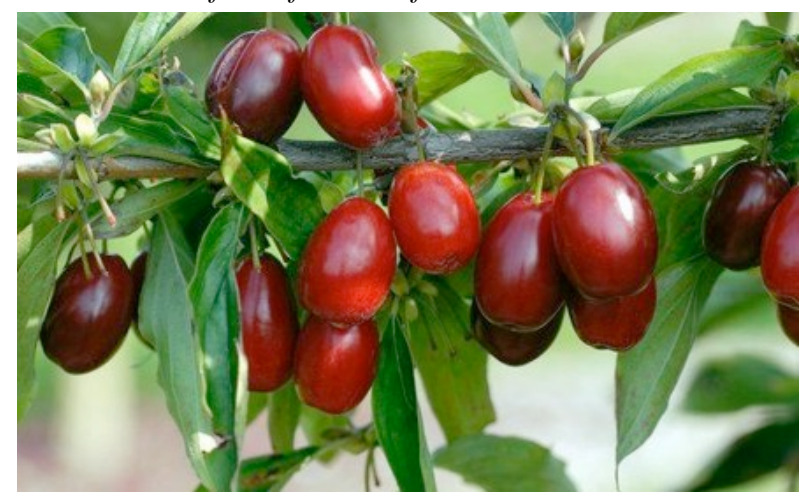

Figure 1. The fruit of Cornus mass.L
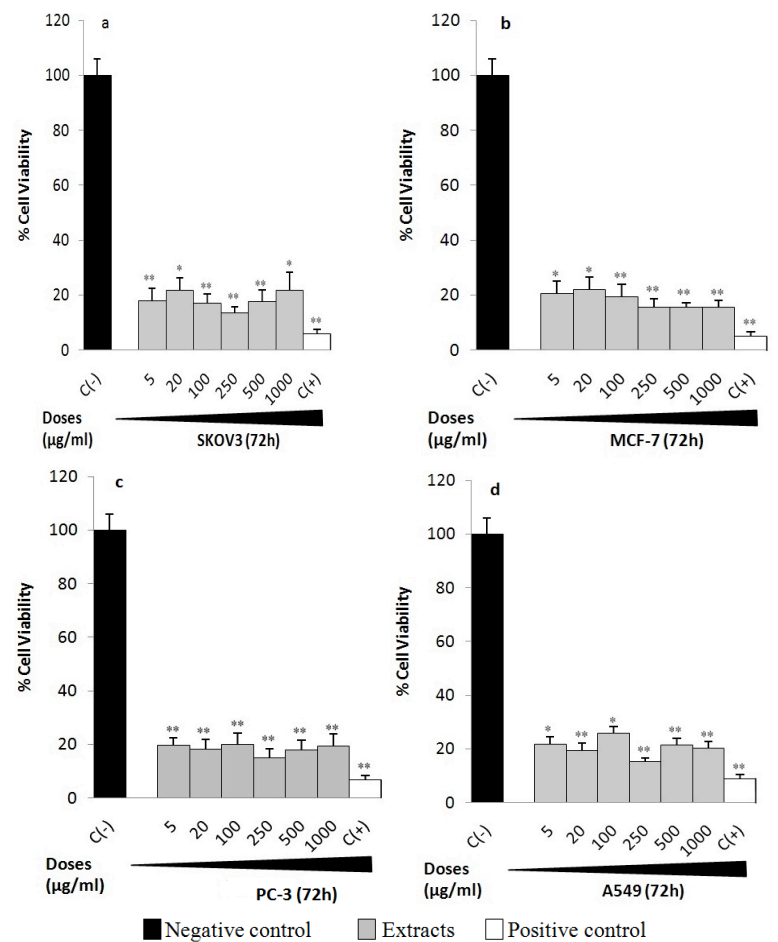

Figure 2. CM Extract Inhibit Different Human Cancer Cell Proliferation. ${ }^{*} \mathrm{p}<0.01 ; * \mathrm{*}<0.001$, compared to the negative control

divergent flavonoids especially the ANTs.

The total polyphenol content in cornelian cherries grown in Turkey ranges between 280 and $580 \mathrm{mg} / 100$ g FM(Tural and Koca, 2008). The Cornus mas grown in the Czech Republic contains 210mg/100g FW (Rop O. et al., 2010) .The Bulgarian cultivars of cornelian cherries contain comparable to other reports amounts of total polyphenols in the range $280-460 \mathrm{mg} / 100 \mathrm{~g}$ FM (Marinova et al., 2005) . Total anthocyanin content in Cornus mas was reported as being on average $223.0 \mathrm{mg}$ per 100g (Pantelidis et al., 2007) and between 95 and $107 \mathrm{mg} / 100 \mathrm{~g}$ FM (Tural and Koca, 2008).The broad range of anthocyanin concentrations for Polish cultivars of cornelian cherries is reported $27-160 \mathrm{mg} / 100 \mathrm{~g}$ FM. Methanolic extract of CM from Poland represent 339.36 $\mathrm{mg} \mathrm{Galic} \mathrm{Acid/100} \mathrm{g} \mathrm{FM} \mathrm{of} \mathrm{TPC} \mathrm{and} 63.86 \mathrm{mg}$ Rutin/100 g FM of TFC. DPPH IC $_{50}$ was $1.96 \mathrm{mmol} \mathrm{TE} / 100 \mathrm{~g}$ FM. In our study, Hydroalcholic extract of Iranian CM showed a higher amount of total polyphenols, up to $1310.23 \mathrm{mg} \mathrm{GAE} / 100 \mathrm{~g}$ FM, TFC was determined $56 \mathrm{mg}$ 
Qurcetin/100g FM. In our study, HAE of CM exhibit a high antioxidant activity, as DPPH $\mathrm{IC}_{50}$ (concentration of antioxidant required to scavenge $50 \%$ of DPPH $\bullet$ radicals) was determined $2.46 \mu \mathrm{g} / \mathrm{ml}$.

In course of our interest on toxicological properties of this high antioxidant extract, we investigated the selective cytotoxicity of CM extract on a series of human cancers including ovarian cancer cells (SKOV3), breast adenocarcinoma cells (MCF-7), prostate adenocarcinoma cells (PC-3) and lung non small cancer cells (A549) by MTT assay. We specially selected these cancer cells because each displays a high propensity for metastasis in vivo. It is shown that MCF-7 cells form tumors when injected into athymic nude mice. These tumors are able to metastasize to lungs, liver and spleen. MCF-7 cells secrete into the culture media collagenases able to lyse types I and IV collagens. At the other hand, PC-3 cells have high metastatic potential to bone compared to other prostate cell lines such as DU145 cells which have a moderate metastatic potential and to LNCaP cells which have low metastatic potential (Sanchez-Sweatman et al., 1998). Lung small cell adenocarcinoma is a rapid growth tumor with high propensity for invasion and metastasis. This cell line frequently use for induction of lung metastasis in mice (Shindo-Okada et al., 2002) Similar to MCF-7, SKOV3 cells are among the aggressive and the most common gynecologic cancer in women, however the unpredicted behavior of SKOV3 differ it from other ER+ cancer cells as well as MCF-7. Both MCF-7 and SKOV3 have the receptors for estrogen $(\mathrm{ER}+)$ and basically they should proliferate in response to estrogen, however practically $\mathrm{ER}+\mathrm{SKOV} 3$ cells are irresponsive to both estrogen and its analogues and this feature makes it a good candidate for studding the mechanism by which ER+cells become unresponsive to estrogen and anti-estrogen therapies. As some polyphenols can interfere with aromatase activity and so hinder synthesis of estrogen which acts as a main growth promoting factor on cancer cells, so we used both hormone responsive and irresponsive cells to discern the selective effects of high polyphenolic extract of CM fruit on these cells.

The results of following study showed that in all doses, significant or very significant difference was observed between treated and untreated controls in a dose independent manner (Figure 2, Figure 3). In all cell lines, $5 \mu \mathrm{g} / \mathrm{ml}$ of CM extract resulted in $>50 \%$ growth inhibition of treated cells which account for the high toxicity profile of hyroalcoholic extract of CM (Table1).

In case of ovarian cancer cells, the maximum growth inhibition of $86.5 \%$ was obtained at doses $250 \mu \mathrm{g} / \mathrm{ml}$, value close to positive control $(20 \mu \mathrm{g} / \mathrm{ml}$ Toxol used as positive control and it caused to $93.76 \%$ growth inhibition of SKOV3 cancer cells) meanwhile dose $20 \mu \mathrm{g} / \mathrm{ml}$ and $1000 \mu \mathrm{g} / \mathrm{ml}$ of CM extarct caused to the lowest growth inhibition of $78.2 \%$. The mean growth inhibition in these cells was $81.77 \%$.

In MCF-7 cancer cells, the maximum growth inhibition of $84.54 \%$ was obtained at doses $250 \mu \mathrm{g} /$ $\mathrm{ml}$, value comparable to that of $20 \mu \mathrm{g} / \mathrm{ml}$ Toxol which caused to $95.1 \%$ growth inhibition of MCF-7 breast adenocarcinoma cells. The lowest growth inhibition of
$77.8 \%$ was obtained at dose $20 \mu \mathrm{g} / \mathrm{ml}$ of $\mathrm{CM}$ extract. The mean growth inhibition was $81.85 \%$.

In PC-3 prostate adenocarcinoma cells, $\mathrm{CM}$ extract caused to the maximum growth inhibition of $85.0 \%$ at doses $250 \mu \mathrm{g} / \mathrm{ml}$. In this cell line, $20 \mu \mathrm{g} / \mathrm{ml}$ Toxol caused to 93.1\% growth inhibition of PC-3 cancer cells meanwhile dose $5 \mu \mathrm{g} / \mathrm{ml}$ and $100 \mu \mathrm{g} / \mathrm{ml}$ of CM extract caused to the lowest growth inhibition $80.25 \%$ and $80.12 \%$, respectively. The mean growth inhibition in these cells was $81.61 \%$ (Table 1, Figure 2).

In case of A549 cancer cells, the maximum growth inhibition of $84.75 \%$ was obtained at doses $250 \mu \mathrm{g} / \mathrm{ml}$ $.20 \mu \mathrm{g} / \mathrm{ml}$ Toxol caused to $90.25 \%$ growth inhibition of A549 cells. In this cells, dose $100 \mu \mathrm{g} / \mathrm{ml}$ caused to the lowest growth inhibition of $74.08 \%$. The mean growth inhibition in these cells was $79.31 \%$ (Table1, Figure 3).

In all cancer cells, $\mathrm{CM}$ extract reduced the cell viability to values below $26 \%$, even the lowest doses. In this regard, CM extract caused to $\sim 82 \%$ growth inhibition of SKOV3, MCF-7, PC-3 cancer cells and $\sim 79.3 \%$ growth arrest of A549 cells. At the other hand, it seemed that lung non small cell cancer cells were the least responsive cells to cytotoxic properties of CME compared to the other studied cancer cells. This finding could be attributed to the high growth rate of A549 cells in the culture that resulted in a subtle difference in the growth inhibition of different cancer cell. At the other hand, it seems that different cancer cells response better to the lower doses of $\mathrm{CM}$ extract, as in many cases ,doses lower than $250 \mu \mathrm{g} /$ $\mathrm{ml}$ caused to $>80 \%$ cell growth inhibition . Except A549 cells, surprisingly, the toxicity of the extract was reduced at doses $>500 \mu \mathrm{g} / \mathrm{ml}$ which indicates to the importance of prior dose optimization of this extract.

\section{Conclusion}

Altogether, to our best knowledge, this is a first study that evaluated toxicity of a high polyphenolic content CM extract on different human cancer cells in vitro. Our results indicated that hydoalcholic extract of CM possess a high potency to inhibit proliferation of different tumors cells in a dose independent manner suggesting that an optimal biological dose is more important and relevant than a maximally tolerated one.

\section{Acknowledgements}

This study is funded by a grant from Student Research Committee (SRC), Tabriz, Iran.

\section{References}

Abbasi MM, Jahanban-Esfahlan R, Monfaredan A, et al (2014). Oral and IV dosages of doxorubicin-methotrexate loadednanoparticles inhibit progression of oral cancer by downregulation of matrix methaloproteinase 2 expression in vivo. Asian Pac J Cancer Prev, 15, 10705-11.

Brand-Williams W, Cuvelier M, Berset C (1995). Use of a free radical method to evaluate antioxidant activity. LWT-Food Sci Technol, 28, 25-30.

Du C-T, Francis FJ (1937). Anthocyanins from Cornus mas. Phytochemistry, 12, 2487. 
Jahanban-Esfahlan A, Jahanban-Esfahlan R, jamei R, et al (2012). Morphology and physicochemical properties of 40 genotypes of almond (Amygdalus communis L.) fruits. Euro J Exp Bio, 2, 2456-64.

Jahanban-Esfahlan A, Jamei R, Jahanban-Esfahlan R (2010). The importance of almond (Prunus amygdalusL.) and its by-products. Food Chem, 120, 349-60.

Jahanban Esfahlan R, Zarghami N, Rahmati-Yamchi M, et al (2011). Quantification of steroid receptors gene expression in breast cancer patients: possible correlation with serum level of adipocytokines. J Cancer Therapy, 2, 659-65.

Marinova D, Ribarova F, Atanassova M (2005). Total phenolics and total flavonoids on Bulgarian fruits and vegetables. $J$ Univeristy Chem Technol Metallurgy, 40, 255-60.

Pantelidis GE, Vasilakakis M, Manganaris GA, et al (2007). Antioxidant capacity, phenol, anthocyanin and ascorbic acid contents in raspberries, blackberries, red currants, gooseberries and Cornelian cherries. Food Chem, 102, 777-83.

Pyrkosz-Biardzka A, Kucharska AZ, Sokol-Letowska A, et al (2014). A comprehensive study on antioxidant properties of crude extracts from fruits of berberis vulgarisL., Cornus masL. and Mahonia aquifoliumNutt. Pol J Food Nutr Sci, 64, 91-9.

Rop O, Mleck J, Kramarova D, et al (2010). Selected cultivars of cornelian cherry (Cornus mas L.) as a new food source for human nutrition. Afr J Biotechnol, 9,1205-10.

Seeram NP, Schutzki R, Chandra A, et al (2002). Characterization, quantification, and bioactivities of anthocyanins in Cornus species. J Agric Food Chem, 50, 2519-23.

Shindo-Okada N, Takeuchi K, Han BS, et al (2002). Establishment of cell lines with high and low metastatic potential from A549 human lung adenocarcinoma. Jpn J Cancer Res, 93, 50-60.

Sineh Sepehr K, Baradaran B, Mazandarani M, et al (2014). Growth-inhibitory and apoptosis-inducing effects of Punica granatum L. var. spinosa (Apple Punice) on fibrosarcoma cell lines. ISRN Pharm, 4, 583-90.

Singleton V, Rossi JA (1965). Colorimetry of total phenolics with phosphomolybdic-phosphotungstic acid reagents. Am J Enol Viticulture, 16, 144-58.

Tural S, Koca I (2008). Physico-chemical and antioxidant properties of cornelian cherry fruits (Cornus masL.) grown in Turkey. Scientia Horticulturae, 46, 294-362.

Valiyari S, Jahanban-Esfahlan R, Zare Shahneh F, et al (2013). Cytotoxic and apoptotic activity of Scrophularia oxysepala in MCF-7 human breast cancer cells. Toxicol Environmental Chem, 95, 1208-20.

Zhishen J, Mengcheng T, Jianming W (1999). The determination of flavonoid contents in mulberry and their scavenging effects on superoxide radicals. Food Chemistry, 64, 555-9. 